\title{
Combining organometallic and Werner-type coordination sites in highly preorganized heterobimetallic systems
}

\author{
Jens C. Röder ${ }^{\text {a }}$, Franc Meyer ${ }^{\mathrm{a}, *}$, Rainer F. Winter ${ }^{\mathrm{b}}$, Elisabeth Kaifer ${ }^{\text {a }}$ \\ a Anorganisch-Chemisches Institut der Universität Heidelberg, Im Neuenheimer Feld 270, D-69120 Heidelberg, Germany \\ ${ }^{\mathrm{b}}$ Institut für Anorganische Chemie der Universität Stuttgart, Pfaffenwaldring 55, D-70569 Stuttgart, Germany
}

\begin{abstract}
A first example of a novel class of preorganized bimetallic complexes is reported, in which both an organometallic $\mathrm{CpMn}(\mathrm{CO})_{2}$ fragment and a classical Werner-type coordination site are arranged in close proximity by means of a bridging pyrazolate. The synthetic route starts from $\mathrm{N}$-protected bis(chloromethyl)pyrazole and involves sequential attachment of the manganese part and the chelating $\mathrm{N}$-donor compartment, bis(pyridylmethyl)amine, at the different sides of the ligand backbone. Pyrazole binding to the manganese(I) is achieved by photoinduced substitution of $\mathrm{CO}$, and the adjacent $\mathrm{N}_{4}$-coordination pocket is suited to accommodate a second metal ion. The heterodinuclear $\mathrm{MnZn}$ complex $\mathbf{4}$ is characterized crystallographically and its redox chemistry investigated by spectroelectrochemical methods. (C) 2002 Elsevier Science B.V. All rights reserved.
\end{abstract}

Keywords: Bridging ligands; N-functionalized cyclopentadienyl ligands; Manganese; Zinc; Bimetallic complexes

\section{Introduction}

Complexes of cyclopentadienyl $(\mathrm{Cp})$ ligands bearing functional amino or amido side chains are receiving enormous attention in present organometallic chemistry $[1,2]$. While the donor substituent tethered to the $\mathrm{Cp}$ moiety might serve an intramolecular function, e.g. acting as a (sometimes hemilabile) chelate donor in generic type A complexes (Scheme 1) [3,4], it may also serve an intermolecular function, e.g. by anchoring to a solid support or providing solubility [3]. It suggests itself to also consider the donor substituent connected to the $\mathrm{Cp}$ ring as a bridging group in dinuclear $\mathrm{Cp}$ complexes, in which the two proximate metal ions are well preorganized for cooperative action. With this intention in mind we recently put forward a novel bimetallic approach $\mathbf{B}$ where a pyrazolate group linking

* Corresponding author. Present address: Institut für Anorganische Chemie, Universität Göttingen, Tammannstr. 4, D-37077 Göttingen, Germany. Tel.: + 49-551-393012 + 49-6221-54-8315; fax: + 49-622154-5707.

E-mail address: franc.meyer@urz.uni-heidel berg.de (F. Meyer). two $\mathrm{Cp}$ units acts both as an intramolecular $\mathrm{N}$-donor and as a bridging unit spanning two-metal ions [5].
2

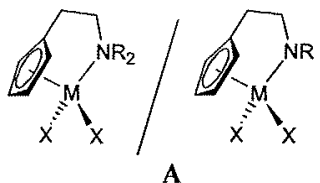

2

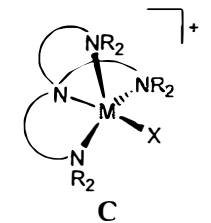

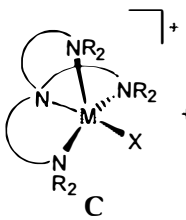<smiles>[X]C1([X])NCCC2=CCCC21[R]</smiles>
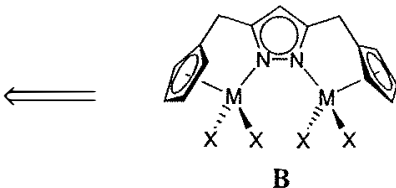

B

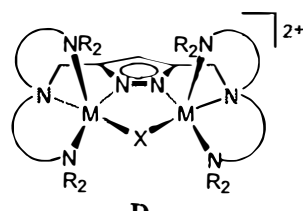

D

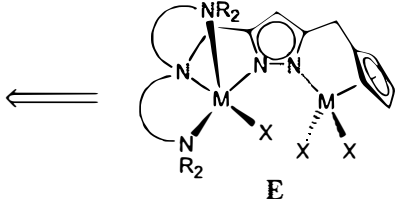

Scheme 1. 


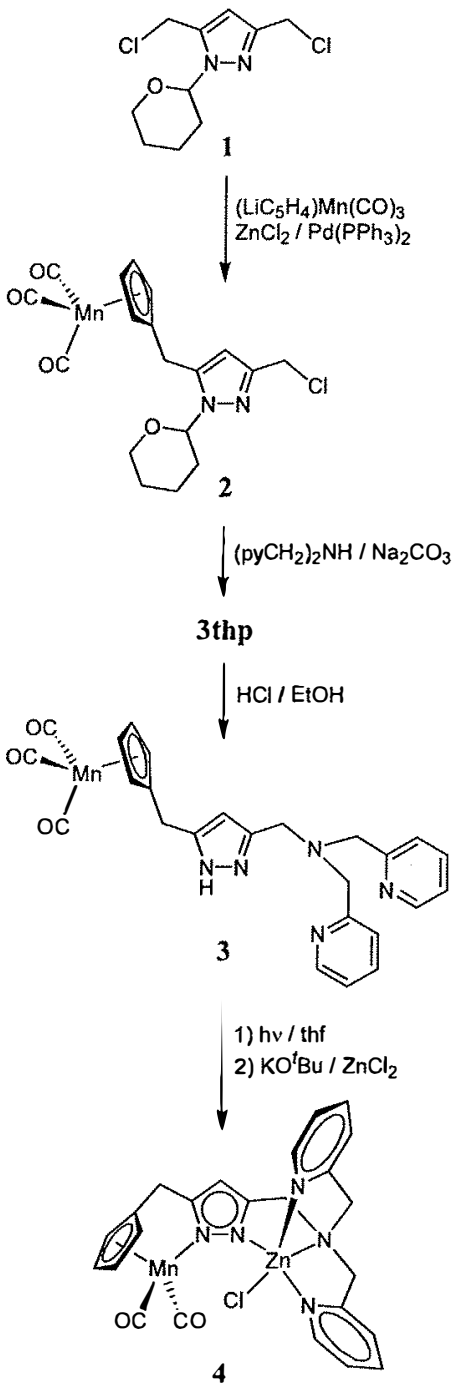

Scheme 2 .

In a certain way this concept arises from previous investigations dealing with the functional principles of natural metalloenzymes that contain di- or oligonuclear active sites. For such bioinorganic systems it is well known that cooperativity of two adjacent metal ions enables very particular and efficient transformations of small substrate molecules [6]. The general strategy outlined in Scheme 1, i.e. the formal coupling of two $\mathrm{N}$-containing ligand compartments via a functionalized pyrazolate to constitute a preorganized dinuclear scaffold, has indeed successfully been employed for achieving cooperative effects in biomimetic coordination compounds when using all-Werner-type donor sets (C and D) $[7,8]$. Accordingly, type $\mathbf{B}$ systems are expected to give rise to some novel organometallic chemistry where two adjacent metal ions work in concert $[5,9]$. A further extension of this chemistry is the combination of each one type $\mathbf{A}$ and one type $\mathbf{C}$ subunit in unsymmetrical dinuclear systems $\mathbf{E}$, i.e. the assembly of both Werner-type and organometallic fragments in a preor-

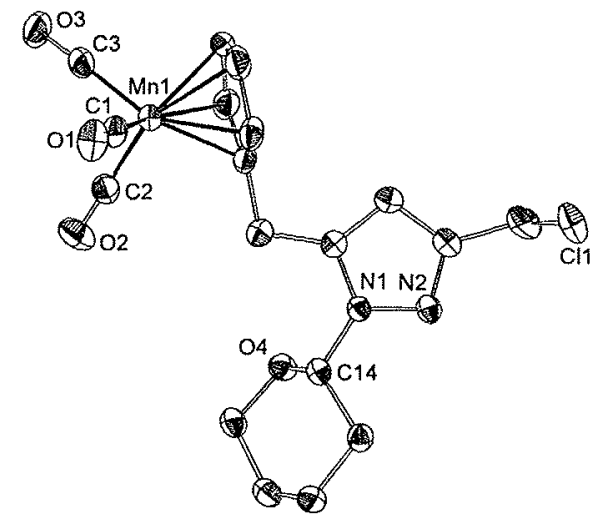

Fig. 1. View of the molecular structure of 2 . In the interests of clarity all hydrogen atoms have been omitted. Selected atom distances $(\AA)$ and angles $\left({ }^{\circ}\right)$ : $\mathrm{N} 1-\mathrm{N} 2,1.368(2) ; \mathrm{O} 1-\mathrm{Cl}, 1.158(3) ; \mathrm{O} 2-\mathrm{C} 2,1.150(3)$; O3-C3, 1.142(3); Mnl-C2, 1.786(3); Mnl-C2, 1.790(3); Mnl-C3, 1.797(3); Mnl-C4, 2.146(2); Mnl-C5, 2.146(3); Mn 1-C6, 2.137(3); $\mathrm{Mnl}-\mathrm{C} 7, \quad 2.117(3) ; \quad \mathrm{Mnl}-\mathrm{C} 8, \quad 2.136(3) ; \quad \mathrm{C} 2-\mathrm{Mnl}-\mathrm{Cl}, \quad 93.3(2) ;$ C2-Mn1-C3, 88.7(2), Cl-Mn1-C3, 92.7(2).

ganized bimetallic array. The present contribution is a report on the synthesis and characterization of a first type $\mathbf{E}$ heterobimetallic complex.

\section{Results and discussion}

The crucial first step of the synthetic route that finally led to type $\mathbf{E}$ bimetallic systems was found adventitiously when we tried to scout a new access to type B compounds. N-protected bis(chloromethyl)pyrazole (1) (Scheme 2) [5] appeared as a suitable starting material for the synthesis of multidentate ligands for type $\mathbf{B}$ complexes. However, while indenyl- or fluorenyl side arms could readily be introduced via nucleophilic substitution reactions [5], this synthetic route proved unsuited for parent $\mathrm{Cp}^{-}$, in which case predominant formation of polymeric material was observed. We next employed $\mathrm{CpMn}(\mathrm{CO})_{3}$ as a 'protected' form of $\mathrm{Cp}$, i.e. we set out to prepare the desired type B system directly as the metal complex. Treatment of $\mathbf{1}$ with lithiated $\mathrm{CpMn}(\mathrm{CO})_{3}$ did not lead to any observable reaction, but a palladium-catalyzed cross coupling protocol developed recently [10] turned out to be more successful. It involves transmetallation of the lithiated $\mathrm{Cp}$ compound to the zinc derivative and the use of a $\operatorname{Pd}\left(\mathrm{PPh}_{3}\right)_{2}$ catalyst [11] according to the procedure outlined in Scheme 2. The monosubstitution product 2 was isolated in good yield and fully characterized. Introduction of a second $\mathrm{CpMn}(\mathrm{CO})_{3}$ moiety could not be achieved starting from 1, even after extensive variation of the reaction conditions [12].

The regiochemistry of the substitution reaction leading to $\mathbf{2}$ was elucidated by a crystallographic analysis of single crystals grown from a $\mathrm{CH}_{2} \mathrm{Cl}_{2}$-light petroleum solution. The structure of $\mathbf{2}$ is depicted in Fig. 1; all 
molecular parameters are as expected. Substitution has obviously occurred in a selective manner within the side arm next to the thp protecting group. At this point we can only speculate about the reasons for the observed regiochemistry. While it is tempting to assume anchimeric assistance of the thp-oxygen atom to be responsible for facilitating nucleophilic substitution on that particular side of the difunctionalized starting material, other (electronic) effects cannot be fully excluded.

Sole isolation of the monosubstitution product 2 identifies this approach as a dead end with respect to the sought-after type B systems. However, the remaining reactive $\mathrm{Cl}$ site in $\mathbf{2}$ now enables the attachment of other coordination compartments. This does in fact open access to novel unsymmetrical bimetallic type $\mathbf{E}$ complexes, as exemplified here by the synthesis of compound 3 bearing a chelating di(2-picolyl)amine donor side arm (Scheme 2). Deprotection of the primary thp-containing product (3thp) is readily achieved by

Table 1

IR absorptions in the $\mathrm{CO}$ stretching range; values in $\mathrm{cm}^{-1}$

\begin{tabular}{lll}
\hline $\mathbf{2}^{\mathrm{a}}$ & 2023 & 1921 \\
$\mathbf{3}^{\text {thp }}{ }^{\mathrm{b}}$ & 2014 & 1922 \\
$\mathbf{3}^{\mathrm{b}}$ & 2013 & 1917 \\
$\mathbf{4}^{\mathrm{a}}$ & 1897 & 1820 \\
$\mathbf{4}^{\mathrm{c}}$ & 1910 & 1835 \\
$\mathbf{4}^{+\mathrm{c}}$ & 2041 & 1964
\end{tabular}

${ }^{\mathrm{a}} \mathrm{KBr}$ pellets.

${ }^{\mathrm{b}}$ Film.

c Dichloroethane solution.

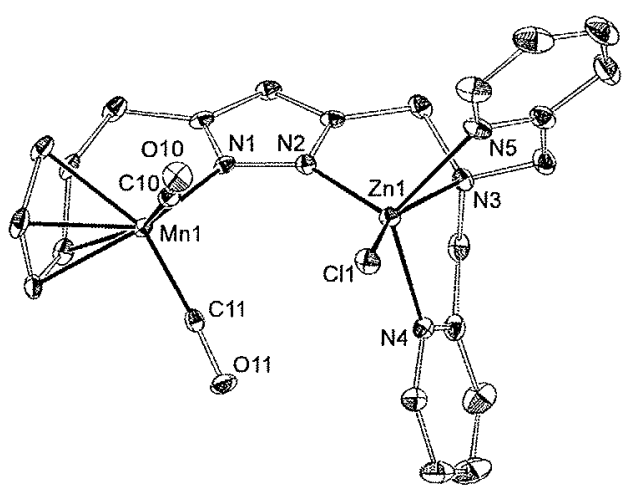

Fig. 2. View of the molecular structure of 4. In the interests of clarity all hydrogen atoms have been omitted. Selected atom distances $(\AA)$ and angles $\left({ }^{\circ}\right)$ : $\mathrm{N} 1-\mathrm{N} 2,1.368(3)$; $\mathrm{O} 10-\mathrm{Cl} 0,1.170(3)$; O11-Cl1, 1.165(3); Znl-N2, 2.001(2); Znl-N3, 2.297(2); Znl-N4, 2.109(2); $\mathrm{Znl-N5}$, 2.172(2); Znl-Cll, 2.289(2); Mnl-N1, 2.018(2); Mnl-C5, 2.147(2); Mnl-C6, 2.146(2); Mnl-C7, 2.128(3); Mnl-C8, 2.124(3); Mnl-C9, 2.151(3); Mnl-Cl0, 1.766(3); Mnl-C11, 1.772(2); $\mathrm{Mnl} \cdots \mathrm{Zn1}, 4.152 ; \mathrm{N} 2-\mathrm{Znl}-\mathrm{N} 3,78.88(8) ; \mathrm{N} 2-\mathrm{Znl}-\mathrm{N} 4,109.87(8) ;$ N2-Znl-N5, 110.66(8); N2-Zn1-Cll, 123.19(6); N3-Zn1-Cll, 157.31(6); N4-Zn1-Cll, 98.43(6); N5-Zn1-Cll, 92.22(6); Cl0-Mnl-Cl1, 93.1(2); Cl0-Mnl-Nl, 100.3(2); Cll-Mnl-Nl, 98.32(9). treatment with acid. The resulting compound 3 provides a tripodal tetradentate $\mathrm{N}_{4}$ coordination pocket next to an organometallic fragment, where the former should be suited to accommodate a variety of different metal ions.

Photolability of one $\mathrm{CO}$ ligand in $\mathrm{CpMn}(\mathrm{CO})_{3}$ and its derivatives is well established [13]. Accordingly, photoinduced $\mathrm{CO}$ substitution in $\mathbf{3}$ leads to in tramolecular $\mathrm{N}$-coordination of the pyrazote heterocycle, and subsequent deprotonation and treatment with $\mathrm{ZnCl}_{2}$ affords the heterobimetallic complex 4 . The composition of the pale yellow complex 4 was initially deduced from spectroscopic evidence and from a high resolution mass spectrum showing a signal around $m / z=567$ with an isotopic distribution pattern corresponding to the molecular ion $\mathbf{4}^{+}$. While $\mathbf{2}$, 3thp and $\mathbf{3}$ all show an IR spectroscopic pattern in the $\mathrm{CO}$ stretching region that is typical for a $\mathrm{CpMn}(\mathrm{CO})_{3}$ unit (i.e. a sharp band at 2013-2023 $\mathrm{cm}^{-1}\left(A_{1}\right.$ mode) and a broad band of higher intensity at $1922-1917 \mathrm{~cm}^{-1}$ ( $E$ mode); see Table 1) [14], a significant shift to lower wavenumbers in 4 (two sharp bands at 1897 and $1820 \mathrm{~cm}^{-1}$ of almost equal intensity) is indicative of $\mathrm{CO}$ replacement by the pyrazolate and formation of a $\mathrm{CpMn}(\mathrm{CO})_{2}$ fragment. The anticipated constitution of $\mathbf{4}$ could be confirmed by an X-ray crystallographic analysis of single crystals obtained from a saturated $\mathrm{CH}_{2} \mathrm{Cl}_{2}$ solution. The molecular structure of 4 is depicted in Fig. 2 together with selected atom distances and bond angles.

In 4 , the pyrazolate bridge spans the $\mathrm{CpMn}(\mathrm{CO})_{2}$ fragment and the zinc(II) ion $[d(\mathrm{Mn} \cdots \mathrm{Zn}=4.152 \AA)]$ with both metal ions located roughly within the plane defined by the pyrazolate heterocycle [out of the plane by $0.096 \AA(\mathrm{Zn})$ and $0.189 \AA(\mathrm{Mn})]$. The $\mathrm{N}_{4}$ coordination compartment nesting the zinc(II) ion is reminiscent of the well-known mononucleating tris(2-pyridylmethyl)amine (tmpa) systems. However, while mononuclear zinc(II) chloride complexes of tmpa-type ligands usually adopt a trigonal-bipyramidal (TB-5) structure with the bridgehead $\mathrm{N}$ atom and the $\mathrm{Cl}$ coligand in the axial positions $[15,16]$, the zinc coordination sphere in $\mathbf{4}$ is severely distorted towards a square-pyramide (SPY5) with the pyrazolate-N2 in the apical position. The degree of trigonality can be evaluated by means of the angular structural parameter $\tau=(\beta-\alpha) / 60$ introduced by Addison et al. [17], where $\alpha$ and $\beta$ represent the two largest angles around the central atom with $\beta>\alpha$ (a perfect TB-5 structure is associated with $\tau=1$, while $\tau=0$ is expected for ideal SPY -5 geometry). $\tau$ values in the range 0.93-0.99 are generally observed for the [tmpaZnCl] ${ }^{+}$system [15]. In contrast, $\tau=0.57$ is calculated for $\mathrm{Znl}$ in 4, confirming a coordination geometry intermediate between TB-5 and SPY-5, which is accompanied by comparatively long $\mathrm{Zn}-\mathrm{Cll}$ and $\mathrm{Zn}-\mathrm{N} 3$ bonds $(d(\mathrm{Zn}-\mathrm{Cl})=2.289(1) \AA$ in 4 vs. $2.271-2.275 \AA$ in $[\mathrm{tmpaZnCl}]^{+} ; d(\mathrm{Zn}-\mathrm{N} 3)=2.297(2) \AA$ vs. $2.228-$ 


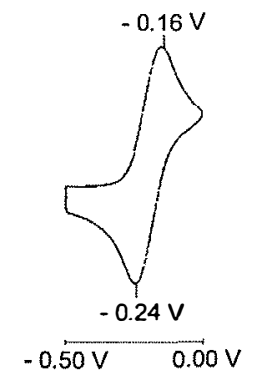

Fig. 3. Cyclic voltammogram of 4 in $\mathrm{CH}_{2} \mathrm{Cl}_{2}$. Potentials are given in volts versus the saturated calomel electrode (SCE).

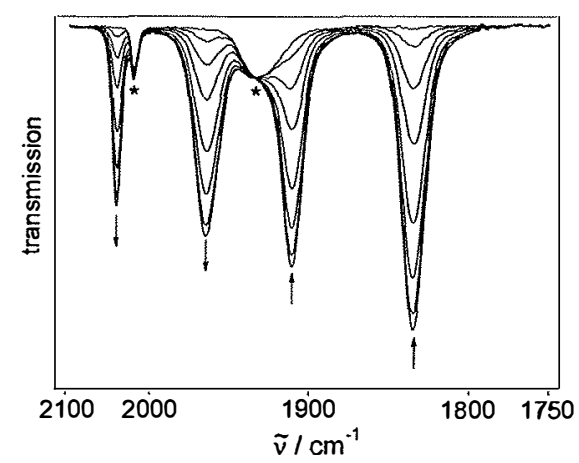

Fig. 4. IR spectroscopic changes during gradual oxidation of $\mathbf{4}$ in an OTTLE cell. The asterisks mark an impurity (presumably the $\mathrm{Mn}(\mathrm{CO})_{3}$ precursor of 4 ).

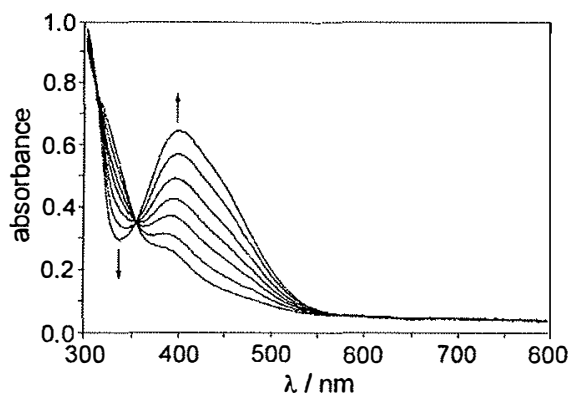

Fig. 5. UV - vis spectroscopic changes during gradual oxidation of 4 in an OTTLE cell.

$2.271 \AA$ ) [15]. We consider steric hindrance between the $\mathrm{Cl}$ atom and the Mn-bound $\mathrm{CO}$ ligands within the bimetallic pocket as the likely reason for this geometric distortion: determined by the rigid bimetallic scaffold, rather short $\mathrm{Cl} \cdots \mathrm{CO}$ distances are enforced in $4[d$ $(\mathrm{Cll} \cdots \mathrm{Cl} 0 / \mathrm{O} 10)=3.56 / 3.54 \AA$ ] , preventing a more linear N3-Zn1-Cll arrangement. Also imposed by the rigid chelating ligand framework, the $\mathrm{N}-\mathrm{Mn}-\mathrm{CO}$ bond angles are somewhat widened $\left[98.32(9)\right.$ and $\left.100.3(2)^{\circ}\right]$. A CSD search [18] revealed that complexes of $\mathrm{CpMn}(\mathrm{CO})_{2}$ fragments with $\mathrm{N}$-donor ligands not tethered to the $\mathrm{Cp}$ usually have $\mathrm{N}-\mathrm{Mn}-\mathrm{CO}$ bond angles in the range $92.6-98.1^{\circ}$.

A cyclic voltammogram of 4 in $\mathrm{CH}_{2} \mathrm{Cl}_{2}$ solution features a reversible redox wave at $E_{1 / 2}=-0.20 \mathrm{~V}$
(Fig. 3) [19], which we assign to the formation of the $\mathrm{Mn}^{\mathrm{II}}\left(\mathrm{d}^{5}\right)$ species. No further redox processes are detectable in the potential range -1.6 to $+1.6 \mathrm{~V}$. Oxidation potentials of $\mathrm{CpMn}(\mathrm{CO})_{2} \mathrm{~L}$ complexes are known to vary over a potential range of more than $2 \mathrm{~V}$, depending of the nature of the ligand $L$ [20-23]. The rather low oxidation potential of $\mathbf{4}$ indicates significant stabilization of the $\mathrm{Mn}^{\mathrm{II}}$ state by the anionic pyrazolate ligand and reflects the high nucleophilicity of the N-heterocycle [22].

To characterize the oxidized $\mathrm{Mn}^{\mathrm{II}}$ species $4^{+}$, the oxidation of 4 in dichloroethane was followed by IRand UV-vis spectroscopy in an OTTLE cell (Figs. 4 and 5). Upon gradual electrolysis of 4 , the pair of $\mathrm{CO}$ stretching vibrations at 1835 and $1910 \mathrm{~cm}^{-1}$ decrease at the expense of two new bands at 1964 and 2041 $\mathrm{cm}^{-1}$, thus confirming structural integrity of the $\mathrm{CpMn}(\mathrm{CO})_{2}$ fragment upon generation of $4^{+}$. The lower intensity of the new bands is as expected, since in $\mathrm{M}-\mathrm{CO}$ moieties spectral intensities usually decrease with increasing oxidation state [24]. Likewise, the shift to higher frequencies of $\sim 130 \mathrm{~cm}^{-1}$ is in accordance with a Mn-centered oxidation and reflects the diminished backbonding ability of the oxidized $\mathrm{Mn}^{\mathrm{II}}$. Upon re-reduction, the original spectrum of the starting material 4 is almost restored. In UV-vis spectroelectrochemistry, the oxidation of 4 is accompanied by an increase in absorptivity (Fig. 5) due to the rise of a new band at $400 \mathrm{~nm}$, which we assign to the $\pi($ pyrazolate $) \rightarrow \mathrm{Mn}^{\mathrm{II}}$ LMCT transition.

The $\mathrm{CpMn}(\mathrm{CO})_{2}$ moiety itself is known to be kinetically very stable $[20,23]$ and has been extensively used for the formation of various $\mathrm{CpMn}(\mathrm{CO})_{2} \mathrm{~L}$ complexes $[22,25,26]$. These $\mathrm{CpMn}(\mathrm{CO})_{2} \mathrm{~L}$ compounds, on the other hand, exhibit notorious kinetic lability, in particular in their oxidized $\mathrm{Mn}^{\mathrm{II}}$ form. In $\mathbf{4}$ and $\mathbf{4}^{+}$, however, the rigid chelate arrangement is anticipated to preclude dissociation of the organometallic fragment from the bridging pyrazolate. In addition, the $\pi$ plane of the heterocycle roughly coincides with the mirror plane of the $\mathrm{Mn}(\mathrm{CO})_{2}$ moiety, which is a very favourable structural situation for Mn-pyrazolate $\pi$-interactions and consequently for electronic communication between the $\mathrm{Mn}$ site and the second metal ion. These particular features of the present type of bimetallic complexes in combination with the possibility of accommodating various different metal ions in the $\mathrm{N}_{4}$ pocket and the obvious ease of oxidation of the organometallic part of the bimetallic system - suggests to use the $\mathrm{CpMn}(\mathrm{CO})_{2}$ subunit as an electron reservoir for redox reactions occurring at the adjacent Werner-type site, i.e. for so-called one-site addition two-metal oxidation processes [27].

In conclusion, we have prepared and structurally characterized a novel bimetallic complex 4 , in which a classical Werner-type coordination subunit is located in 
close proximity to a soft organometallic fragment in a predefined manner. The chemistry of such preorganized heterobimetallic systems that incorporate two very distinct sites will be explored in more detail in future work, focusing (i) on the influence of different metal ions in the $\mathrm{N}_{4}$ compartment on the electronic properties of the organometallic site as well as (ii) on the use of the $\mathrm{CpMn}(\mathrm{CO})_{2}$ fragment as an electron reservoir for substrate transformations that proceed via one-site addition two-metal oxidation reactions at the Werner-type metal site.

\section{Experimental}

\subsection{General procedures and methods}

All manipulations were carried out under an atmosphere of dry Ar by employing standard Schlenk techniques or else in a glove box. Solvents were dried according to established procedures. Compound 1 was synthesized according to the reported method [5], all other chemicals were used as purchased. Microanalyses: Mikroanalytische Laboratorien des Organisch-Chemischen Instituts der Universität Heidelberg. IR spectra: Perkin-Elmer 983G; recorded as $\mathrm{KBr}$ pellets. Cyclic voltammetry: PAR equipment, (potentiostat/galvanostat 273), in $0.1 \mathrm{M} \mathrm{NBu}_{4} \mathrm{PF}_{6}-\mathrm{CH}_{2} \mathrm{Cl}_{2}$. Potentials in $\mathrm{V}$ on glassy carbon electrode, referenced to SCE at ambient temperature. UV-vis spectra: Perkin-Elmer Lambda 19. FAB-MS spectra: Finnigan MAT 8230. HR-MS spectra: JEOL JMS700. NMR spectra: Bruker AC 200 at $200.13\left({ }^{1} \mathrm{H}\right)$ and $50.32\left({ }^{13} \mathrm{C}\right) \mathrm{MHz}$, or Bruker DRX 300 at $300.13 \mathrm{MHz}\left({ }^{1} \mathrm{H}\right)$ and $75.47\left({ }^{13} \mathrm{C}\right) \mathrm{MHz}$, or Bruker DRX 500 at $500.13 \mathrm{MHz}\left({ }^{1} \mathrm{H}\right)$ and $125.77\left({ }^{13} \mathrm{C}\right)$ $\mathrm{MHz}$; residual proton signal of the solvent as internal chemical shift reference. Spectroelectrochemistry: Selfconstructed OTTLE cell comprising a Pt-mesh working and counter electrode and a silver wire as pseudo-reference electrode sandwiched in between the $\mathrm{CaF}_{2}$ windows of a conventional liquid IR cell. The working electrode is positioned in the center of the spectrometer beam with all other parts of the cell made non-transparent to the incident beam by means of an absorbing tape [28].

\subsection{Compound 2}

$\mathrm{CpMn}(\mathrm{CO})_{3}(2.00 \mathrm{~g}, 9.80 \mathrm{mmol})$ was dissolved in THF $(50 \mathrm{ml})$ and a $2.5 \mathrm{M}$ solution of $n-\mathrm{BuLi}$ in hexane $(3.90 \mathrm{ml}, 9.80 \mathrm{mmol})$ added via a syringe at $-78{ }^{\circ} \mathrm{C}$. After stirring for $1 \mathrm{~h}$ at low temperature, $\mathrm{ZnCl}_{2}(1.30 \mathrm{~g}$, $9.80 \mathrm{mmol})$ in THF $(20 \mathrm{ml})$ was added and stirring continued for further $1 \mathrm{~h}$. In a separate flask, a solution of the $\operatorname{Pd}(0)$ catalyst $\left[\mathrm{Pd}\left(\mathrm{PPh}_{3}\right)_{2}\right]$ was prepared by reduction of a suspension of $\left[\mathrm{PdCl}_{2}\left(\mathrm{PPh}_{3}\right)_{2}\right](0.07 \mathrm{~g}, 0.10$ mmol) in THF (10 ml) by means of a $1 \mathrm{M}$ solution of DIBAH in hexane $(0.20 \mathrm{ml}, 0.20 \mathrm{mmol})$. The catalyst solution was then transferred to the reaction mixture via a canula, and finally a solution of $1(1.20 \mathrm{~g}, 4.90$ mmol) in THF $(20 \mathrm{ml})$ was added. Stirring was continued for $1 \mathrm{~h}$ at $-78{ }^{\circ} \mathrm{C}$ and further $72 \mathrm{~h}$ at room temperature (r.t.) under $\mathrm{Ar}$ and under exclusion of light. After hydrolyzing by the addition of aqueous $\mathrm{NaCl}$, the organic phase was separated, dried over $\mathrm{MgSO}_{4}$ and the solvent removed under reduced pressure. The product 2 was purified by column chromatography (silica gel, $\mathrm{CH}_{2} \mathrm{Cl}_{2}$-light petroleum 1:1, $R_{\mathrm{f}}$ $\left(\mathrm{Et}_{2} \mathrm{O}\right.$-light petroleum 1:1) $\left.=0.55\right)$. Colorless crystalline material could be obtained by slow diffusion of light petroleum into a solution of the product in a small amount of $\mathrm{CH}_{2} \mathrm{Cl}_{2}$. Yield: $1.53 \mathrm{~g}, 3.60 \mathrm{mmol}, 74 \%$. ${ }^{1} \mathrm{H}-\mathrm{NMR} \quad\left(\mathrm{CDCl}_{3}\right): \quad \delta=1.65-1.69 \quad(\mathrm{br}, \mathrm{m}, \quad 3 \mathrm{H}$, $\mathrm{CH}_{2}^{\text {llp, }}$ 4/5), 1.94-2.12 (br, m, 2H, $\left.\mathrm{CH}_{2}^{\text {thp. } 3 / 4}\right), 2.33$ (br, $\left.\mathrm{m}, \mathrm{lH}, \mathrm{CH}_{2}^{\text {thp, }}{ }^{3}\right), 3.66$ (br, m, $3 \mathrm{H}, \mathrm{CH}_{2} \mathrm{Cp}$ and $\mathrm{CH}_{2}^{\mathrm{thp}, 6}$ ), $4.04\left(\mathrm{~d},{ }^{3} \mathrm{~J}=10.1 \mathrm{~Hz}, 1 \mathrm{H}, \mathrm{CH}_{2}^{\text {thp, }} 6\right), 4.55(\mathrm{~s}, 2 \mathrm{H}$, $\left.\mathrm{CH}_{2} \mathrm{Cl}\right), 4.70\left(\mathrm{~d},{ }^{3} \mathrm{~J}=2 \mathrm{~Hz}, 2 \mathrm{H}, \mathrm{CH}^{\mathrm{CP}}\right), 4.73\left(\mathrm{~d},{ }^{3} \mathrm{~J}=2\right.$ $\left.\mathrm{Hz}, 2 \mathrm{H}, \mathrm{CH}^{\mathrm{CP}}\right), 5.26\left(\mathrm{dd},{ }^{3} \mathrm{~J}=9.7 \mathrm{~Hz} / 2.5 \mathrm{~Hz}, 1 \mathrm{H}\right.$, $\left.\mathrm{CH}_{2}^{\text {thp, }}{ }^{2}\right), 6.11\left(\mathrm{~s}, 1 \mathrm{H}, \mathrm{CH}^{\mathrm{pz}, 4}\right) \cdot{ }^{13} \mathrm{C}-\mathrm{NMR}\left(\mathrm{CDCl}_{3}\right)$ : $\delta=22.3\left(\mathrm{CH}_{2}^{\text {thp, }}{ }^{4}\right), 24.3,24.5\left(\mathrm{CH}_{2}^{\mathrm{thp}}, 5, \mathbf{C H}_{2} \mathrm{Cp}\right), 29.2$ $\left(\mathrm{CH}_{2}^{\text {thp, }} 3\right), 38.8\left(\mathrm{CH}_{2} \mathrm{Cl}\right), 67.4\left(\mathrm{CH}_{2}^{\text {thp, }}{ }^{\text {th }}\right), 81.5,81.8$ $\left(\mathrm{CH}^{\mathrm{CP}}\right), 83.1\left(\mathrm{CH}^{\mathrm{thp}, 2}\right), 101.7\left(\mathbf{C}^{\mathrm{Cp}}\right), 105.6\left(\mathrm{CH}^{\mathrm{pz}, 4}{ }^{4}\right)$, $143.0\left(\mathbf{C}^{\mathrm{pz} .5}\right), 148.8\left(\mathbf{C}^{\mathrm{pz} .3}\right), 224.7(\mathbf{C O})$. IR $(\mathrm{KBr}): 2956$ w, $2859 \mathrm{w}, 2023$ vs, 1921 vs, $1541 \mathrm{w}, 1454 \mathrm{~m}, 1366 \mathrm{w}$, $1252 \mathrm{~m}, 1202 \mathrm{w}, 1124 \mathrm{w}, 1081 \mathrm{~m}, 1075 \mathrm{w}, 1039 \mathrm{~s}, 1002$ m, 920 w, 883 w, 795 w, 732 w, 666 m, 634 s, 536 w. MS (EI); $m / z(\%): 416(20)\left[\mathrm{M}^{+}\right], 332$ (100) $\left[\mathrm{M}^{+}-\right.$ DHP]. Calc. for $\mathrm{C}_{18} \mathrm{H}_{18} \mathrm{ClMnN}_{2} \mathrm{O}_{4}$ (416.73): C 51.87, $\mathrm{H}$ 4.35, N 6.72, Cl 8.51. Anal. Found: C 51.82, H 4.42, N 6.76, $\mathrm{Cl} 8.77 \%$.

\subsection{Compound 3thp}

$\mathrm{Na}_{2} \mathrm{CO}_{3}(4 \mathrm{~g}, 37 \mathrm{mmol})$ was dried at $100{ }^{\circ} \mathrm{C}$ under vacuum for $1 \mathrm{~h}$. After cooling to r.t., a solution of 1 $(1.53 \mathrm{~g}, 3.60 \mathrm{mmol})$ and di(2-picolyl)amine $(0.79 \mathrm{~g}, 3.96$ mmol) in $\mathrm{MeCN}(50 \mathrm{ml}$ ) were added. The suspension was stirred overnight at $75{ }^{\circ} \mathrm{C}$ under exclusion of light, then filtered and the residue washed several times with small portions of $\mathrm{MeCN}$. Evaporation of the combined organic phases yielded a red-brown oil that was purified by Kugelrohr destillation under vacuum to yield $3(1.54 \mathrm{~g}, 2.66 \mathrm{mmol}, 73 \%)$. ${ }^{1} \mathrm{H}-\mathrm{NMR}\left(\mathrm{CDCl}_{3}\right)$ : $\delta=1.61-1.66\left(\mathrm{br}, \mathrm{m}, 3 \mathrm{H}, \mathrm{CH}_{2}^{\text {thp, } 4 / 5}\right), 1.90-2.10(\mathrm{br}, \mathrm{m}$, $\left.2 \mathrm{H}, \mathrm{CH}_{2}^{\text {thp }, 3 / 4}\right), 2.43\left(\mathrm{br}, \mathrm{m}, 1 \mathrm{H}, \mathrm{CH}_{2}^{\mathrm{lth}, 3}\right.$ ), 3.57 (br, m, $\left.1 \mathrm{H}, \mathrm{CH}_{2}^{\mathrm{Llp}, 6}\right), 3.65\left(\mathrm{~s}, 2 \mathrm{H}, \mathrm{CH}_{2} \mathrm{Cp}\right), 3.71\left(\mathrm{~s}, 2 \mathrm{H}, \mathrm{CH}_{2} \mathrm{~N}\right)$, $3.82\left(\mathrm{~s}, 4 \mathrm{H}, \mathrm{NCH}_{2} \mathrm{Py}\right), 4.00\left(\mathrm{~d},{ }^{3} J=10.6 \mathrm{~Hz}, 1 \mathrm{H}\right.$, $\left.\mathrm{CH}_{2}^{\text {thp, } 6}\right), 4.66-4.71\left(\mathrm{br}, \mathrm{m}, 4 \mathrm{H}, \mathrm{CH}^{\mathrm{CP}_{\mathrm{p}}}\right), 5.22\left(\mathrm{~d},{ }^{3} \mathrm{~J}=8.2\right.$ $\left.\mathrm{Hz}, 1 \mathrm{H}, \mathrm{CH}_{2}^{\mathrm{thp}, 2}\right), 6.14\left(\mathrm{~s}, 1 \mathrm{H}, \mathrm{CH}^{\mathrm{pz} .4}\right), 7.11$ (pseudo-t, $\left.{ }^{3} J=6.5 \mathrm{~Hz}, 2 \mathrm{H}, \mathrm{CH}^{\mathrm{py}, 5}\right), 7.54-7.65\left(\mathrm{br}, \mathrm{m}, 4 \mathrm{H}, \mathrm{CH}^{\mathrm{py}, 3 /}\right.$ 4), $8.49\left(\mathrm{~d},{ }^{3} \mathrm{~J}=6.5 \mathrm{~Hz}, 2 \mathrm{H}, \quad \mathrm{CH}^{\mathrm{py}, 6}\right) .{ }^{13} \mathrm{C}-\mathrm{NMR}$ $\left(\mathrm{CDCl}_{3}\right): \quad \delta=22.3 \quad\left(\mathrm{CH}_{2}^{\mathrm{thp}, 4}\right), \quad 24.2, \quad 24.6 \quad\left(\mathrm{CH}_{2}^{\text {thp }, 5}\right.$, $\left.\mathrm{CH}_{2} \mathrm{Cp}\right), 29.3\left(\mathrm{CH}_{2}^{\text {thp }, 3}\right), 51.3\left(\mathrm{CH}_{2} \mathrm{~N}\right), 59.5\left(\mathrm{NCH}_{2} \mathrm{Py}\right)$, 
$67.3\left(\mathrm{CH}_{2}^{\text {thp }, 6}\right), 81.4,81.7,83.0,83.1 \quad\left(\mathrm{CH}^{\mathrm{Cp}}\right), 84.3$ $\left(\mathbf{C H}^{\text {thp.2 }}\right), 102.0\left(\mathbf{C}^{\mathrm{Cp}}\right), 106.1\left(\mathrm{CH}^{\mathrm{pz}, 4}\right), 121.5\left(\mathbf{C H}^{\mathrm{py}, 5}\right)$, $122.6\left(\mathrm{CH}^{\mathrm{py}, 3}\right), 136.0\left(\mathrm{CH}^{\mathrm{py}, 4}\right), 141.2\left(\mathbf{C}^{\mathrm{pz}, 5}\right), 148.7$ $\left(\mathbf{C H}^{\mathrm{py}, 6}\right), 149.2\left(\mathbf{C}^{\mathrm{pz}, 3}\right), 159.5\left(\mathbf{C}^{\mathrm{py}, 2}\right), 224.5(\mathbf{C O}) . \mathrm{IR}$ (film): $3379 \mathrm{w}, 3058 \mathrm{w}, 3000 \mathrm{w}, 2931 \mathrm{~s}, 2843 \mathrm{~m}, 2014 \mathrm{vs,}$ 1922 vs, 1585 s, $1563 \mathrm{~m}, 1549 \mathrm{w}, 1467 \mathrm{~s}, 1428 \mathrm{~s}, 1396 \mathrm{w}$, $1358 \mathrm{w}, 1313 \mathrm{w}, 1258 \mathrm{~m}, 1203 \mathrm{~m}, 1128 \mathrm{~m}, 1080 \mathrm{~s}, 1040$ s, $1003 \mathrm{~m}, 916 \mathrm{w}, 882 \mathrm{w}, 845 \mathrm{w}, 811 \mathrm{w}, 759 \mathrm{~s}, 667 \mathrm{~s}, 635$ s. MS (El); $m / z(\%): 579$ (2) $\left[\mathrm{M}^{+}\right], 403$ (70) $\left[\mathrm{M}^{+}-\right.$ $\left.\mathrm{C}_{6} \mathrm{H}_{6} \mathrm{~N}-3 \mathrm{CO}\right], \quad 319 \quad(35) \quad\left[\mathrm{M}^{+}-\mathrm{C}_{6} \mathrm{H}_{6} \mathrm{~N}-3 \mathrm{CO}-\right.$ DHP]. Calc. for $\mathrm{C}_{30} \mathrm{H}_{30} \mathrm{MnN}_{5} \mathrm{O}_{4}$ (579.52): $\mathrm{C}$ 62.17, $\mathrm{H}$ 5.21, N 12.08. Anal. Found: C 62.33, H 5.27, N $12.30 \%$.

\subsection{Compound 3}

A solution of 3thp (1.54 g, $2.66 \mathrm{mmol})$ in EtOH (20 $\mathrm{ml})$ was treated with ethanolic $\mathrm{HCl}(10 \mathrm{ml})$ and stirred overnight under exclusion of light. Addition of $\mathrm{Et}_{2} \mathrm{O}$ $(100 \mathrm{ml})$ caused precipitation of the hydrochloride salt of 3 as a brownish solid. This was separated by filtration, neutralized with aqueous $\mathrm{Na}_{2} \mathrm{CO}_{3}$ and extracted with several portions of $\mathrm{CH}_{2} \mathrm{Cl}_{2}$. After drying the combined organic phases over $\mathrm{MgSO}_{4}$, the solvent was evaporated to give the crude product as a red-brown oil that was purified by Kugelrohr distillation under vacuum. Yield: $1.31 \mathrm{~g}(2.26 \mathrm{mmol}), 84 \%$. ${ }^{1} \mathrm{H}-\mathrm{NMR}$ $\left(\mathrm{CDCl}_{3}\right): \delta=3.63\left(\mathrm{~s}, 2 \mathrm{H}, \mathrm{CH}_{2} \mathrm{Cp}\right), 3.73\left(\mathrm{~s}, 2 \mathrm{H}, \mathrm{CH}_{2} \mathrm{~N}\right)$, 3.80 (s, $\left.4 \mathrm{H}, \mathrm{NCH}_{2} \mathrm{Py}\right), 4.64$ (s, 2H, $\left.\mathrm{CH}^{\mathrm{Cp}}\right), 4.76(\mathrm{~s}, 2 \mathrm{H}$, $\left.\mathrm{CH}^{\mathrm{Cp}}\right) 6.02\left(\mathrm{~s}, 1 \mathrm{H}, \mathrm{CH}^{\mathrm{pz}, 4}\right), 7.19$ (pseudo-t, ${ }^{3} J=6.5 \mathrm{~Hz}$, $\left.2 \mathrm{H}, \mathrm{CH}^{\mathrm{py}, 5}\right), 7.38\left(\mathrm{~d},{ }^{3} \mathrm{~J}=6.5 \mathrm{~Hz}, 2 \mathrm{H}, \mathrm{CH}^{\mathrm{py}, 3}\right), 7.65$ (pseudo-t, $\left.{ }^{3} J=6.5 \mathrm{~Hz}, 2 \mathrm{H}, \mathrm{CH}^{\mathrm{py}, 4}\right), 8.58\left(\mathrm{~d},{ }^{3} J=6.5\right.$ $\left.\mathrm{Hz}, \quad 2 \mathrm{H}, \quad \mathrm{CH}^{\mathrm{py}, 6}\right) . \quad{ }^{13} \mathrm{C}-\mathrm{NMR} \quad\left(\mathrm{CDCl}_{3}\right): \quad \delta=27.1$ $\left(\mathrm{CH}_{2} \mathrm{Cp}\right), 47.4\left(\mathrm{CH}_{2} \mathrm{~N}\right), 59.1\left(\mathrm{NCH}_{2} \mathrm{Py}\right), 81.4,83.0$ $\left(\mathrm{CH}^{\mathrm{Cp}}\right), 103.5\left(\mathrm{CH}^{\mathrm{pz}, 4}\right), 104.3\left(\mathbf{C}^{\mathrm{Cp}}\right), 122.1\left(\mathrm{CH}^{\mathrm{py}, 5}\right)$, $123.5\left(\mathbf{C H}^{\mathrm{py}, 3}\right), 136.5\left(\mathrm{CH}^{\mathrm{py}, 4}\right), 140.3\left(\mathrm{C}^{\mathrm{pz}, 5}\right), \quad 148.8$ $\left(\mathbf{C H}^{\mathrm{py}, 6}\right), 150.2\left(\mathbf{C}^{\mathrm{pz}, 3}\right), 158.2\left(\mathbf{C}^{\mathrm{py}, 2}\right), 224.9(\mathbf{C O}) . \mathrm{IR}$ (film): 3177 s, 3093 s, 3007 s, 2919 s, 2880 s, 2831 s, 2013 vs, 1917 vs, 1587 s, 1565 s, 1469 s, 1429 s, 1359 m, $1307 \mathrm{w}, 1244 \mathrm{w}, 1146 \mathrm{~m}, 1120 \mathrm{w}, 1089 \mathrm{w}, 1046 \mathrm{w}, 1026$ w, $993 \mathrm{~m}, 836 \mathrm{~m}, 762 \mathrm{~s}, 668 \mathrm{~s}, 634 \mathrm{~s}$. MS (FAB neg); $m / z$ (\%): 494 (100) [ $\mathrm{M}^{-}-\mathrm{H}$ ]. Calc. for $\mathrm{C}_{25} \mathrm{H}_{22} \mathrm{MnN}_{5} \mathrm{O}_{3}$ (495.41): C 60.61, H 4.47, N 14.13. Anal. Found: C $60.80, \mathrm{H} 4.54$, N $14.20 \%$.

\subsection{Compound 4}

A solution of $3(0.26 \mathrm{~g}, 0.52 \mathrm{mmol})$ in THF $(200 \mathrm{ml})$ was irradiated with a high pressure mercury lamp in a quartz schlenk tube at $-40{ }^{\circ} \mathrm{C}$ for $15 \mathrm{~min}$. During this time, the solution became darker while the reaction was followed by IR spectroscopy. After warming to r.t., $\mathrm{ZnCl}_{2}(0.71 \mathrm{~g}, 0.52 \mathrm{mmol})$ and $\mathrm{KO}^{\prime} \mathrm{Bu}(0.58 \mathrm{~g}, 0.52$ mmol) were added and the reaction mixture stirred overnight. After removal of the solvent under reduced pressure, the pale yellow residue was washed with light petroleum, then dissolved in $\mathrm{CH}_{2} \mathrm{Cl}_{2}$ and the crude product 4 precipitated by the addition of $\mathrm{Et}_{2} \mathrm{O}(0.24 \mathrm{~g}$, $0.43 \mathrm{mmol}, 82 \%$ ). Single crystals were obtained from a concentrated $\mathrm{CH}_{2} \mathrm{Cl}_{2}$ solution. ' $\mathrm{H}-\mathrm{NMR}\left(\mathrm{CD}_{2} \mathrm{Cl}_{2}\right): \delta=$ $3.68\left(\mathrm{~s}, 2 \mathrm{H}, \mathrm{CH}_{2} \mathrm{Cp}\right), 3.79\left(\mathrm{~s}, 2 \mathrm{H}, \mathrm{CH}_{2} \mathrm{~N}\right), 4.00(\mathrm{~m}, 4 \mathrm{H}$, $\left.\mathrm{NCH}_{2} \mathrm{Py}\right), 5.16\left(\mathrm{~s}, 4 \mathrm{H}, \mathrm{CH}^{\mathrm{Cp}}\right), 5.66\left(\mathrm{~s}, 1 \mathrm{H}, \mathrm{CH}^{\mathrm{pz}, 4}\right), 7.35$ (br, s, 2H, $\left.\mathrm{CH}^{\mathrm{py}, 5}\right), 7.54$ (br, s, 2H, $\mathrm{CH}^{\mathrm{py}, 3}$ ), 7.92 (br, s, $\left.2 \mathrm{H}, \mathrm{CH}^{\mathrm{py}, 4}\right), 9.47$ (br, s, 2H, CH $\left.{ }^{\mathrm{py}, 6}\right) .{ }^{13} \mathrm{C}-\mathrm{NMR}$ $\left(\mathrm{CD}_{2} \mathrm{Cl}_{2}\right): \quad \delta=27.3 \quad\left(\mathrm{CH}_{2} \mathrm{Cp}\right), \quad 44.3 \quad\left(\mathrm{CH}_{2} \mathrm{~N}\right), \quad 56.8$ $\left(\mathrm{NCH}_{2} \mathrm{Py}\right), 77.5\left(\mathrm{CH}^{\mathrm{Cp}}\right), 98.0\left(\mathrm{CH}^{\mathrm{pz}, 4}\right),\left(\mathbf{C}^{\mathrm{Cp}}\right)$ not observed, $123.7\left(\mathbf{C H}^{\mathrm{py}, 5}\right), 124.9\left(\mathbf{C H}^{\mathrm{py}, 3}\right), 140.3\left(\mathbf{C H}^{\mathrm{py}, 4}\right)$, 151.4, $154.9\left(\mathbf{C H}^{\mathrm{py}, 6}\right),\left(\mathbf{C}^{\mathrm{pz}, 5}\right),\left(\mathbf{C}^{\mathrm{pz}, 3}\right),\left(\mathbf{C}^{\mathrm{py}, 2}\right),(\mathbf{C O})$ not observed. IR (KBr): 3437 s, $2921 \mathrm{~m}, 1897$ vs, 1820 vs, $1601 \mathrm{~m}, 1478 \mathrm{~m} 1432 \mathrm{~m}, 1382 \mathrm{w}, 1336 \mathrm{w}, 1259 \mathrm{~m}, 1100$ w, $1051 \mathrm{w}, 1016 \mathrm{w}, 772 \mathrm{~m}, 659 \mathrm{w}, 644 \mathrm{w}, 634 \mathrm{w}, 610 \mathrm{w}$, 583 w, 476 w, 415 w. MS (FAB); $m / z(\%): 567$ (15)

Table 2

Crystal data and refinement details for 2 and $4 \cdot \mathrm{CH}_{2} \mathrm{Cl}_{2}$

\begin{tabular}{|c|c|c|}
\hline & 2 & 4 \\
\hline $\begin{array}{l}\text { Empirical } \\
\text { formula }\end{array}$ & $\mathrm{C}_{18} \mathrm{H}_{18} \mathrm{ClMnN} \mathrm{Mn}_{4}$ & $\begin{array}{l}\mathrm{C}_{24} \mathrm{H}_{21} \mathrm{ClMnN}_{5} \mathrm{O}_{2} \mathrm{Zn} \cdot \\
\mathrm{CH}_{2} \mathrm{Cl}_{2}\end{array}$ \\
\hline Formula weight & 416.73 & 652.14 \\
\hline $\begin{array}{l}\text { Crystal size } \\
(\mathrm{mm})\end{array}$ & $0.50 \times 0.15 \times 0.15$ & $0.25 \times 0.25 \times 0.08$ \\
\hline Crystal system & Orthorhombic & Triclinic \\
\hline Space group & Pbca & $P \overline{1}$ \\
\hline \multicolumn{3}{|c|}{ Unit cell dimensions } \\
\hline$a(\AA)$ & $20.046(4)$ & $8.270(17)$ \\
\hline$b(\AA)$ & $8.532(17)$ & $9.439(19)$ \\
\hline$c(\AA)$ & $21.548(4)$ & $17.472(4)$ \\
\hline$\alpha\left({ }^{\circ}\right)$ & 90 & $93.34(3)$ \\
\hline$\beta\left({ }^{\circ}\right)$ & 90 & $93.39(3)$ \\
\hline$y\left({ }^{\circ}\right)$ & 90 & $98.79(3)$ \\
\hline$V\left(\AA^{3}\right)$ & $3685.4(13)$ & $1342.4(5)$ \\
\hline$D_{\text {calc }}\left(\mathrm{g} \mathrm{cm}^{-3}\right)$ & 1.502 & 1.613 \\
\hline$Z$ & 8 & 2 \\
\hline$F(000)$ & 1712 & 660 \\
\hline$T(\mathrm{~K})$ & 200 & 200 \\
\hline $\begin{array}{c}\mu\left(\mathrm{Mo}-\mathrm{K}_{\alpha}\right) \\
\left(\mathrm{mm}^{-1}\right)\end{array}$ & 0.071 & 0.071 \\
\hline Index range & $\begin{array}{l}-26 \leq h \leq+25 \\
-10 \leq k \leq+10 \\
-27 \leq l \leq+27\end{array}$ & $\begin{array}{l}-10 \leq h \leq+10 \\
-12 \leq k \leq+12 \\
-21 \leq l \leq+22\end{array}$ \\
\hline $2 \theta$ Range $\left({ }^{\circ}\right)$ & $3.8-55.0$ & $4.4-55.0$ \\
\hline $\begin{array}{l}\text { Measured } \\
\text { reflections }\end{array}$ & 8123 & 8517 \\
\hline $\begin{array}{l}\text { Unique } \\
\text { reflections }\end{array}$ & 4172 & 5789 \\
\hline $\begin{array}{l}\text { Observed } \\
\text { reflections } \\
{[I>2 \sigma(I)]}\end{array}$ & 3079 & 4771 \\
\hline $\begin{array}{l}\text { Refined } \\
\text { parameters }\end{array}$ & 307 & 337 \\
\hline $\begin{array}{l}\text { Residual electron } \\
\text { density } \\
\left(\mathrm{e} \AA^{-3}\right)\end{array}$ & $0.408 /-0.587$ & $0.531 /-0.758$ \\
\hline$R_{1}$ & 0.043 & 0.034 \\
\hline$w R_{2}$ (all data) & 0.112 & 0.080 \\
\hline Goodness-of-fit & 1.037 & 1.026 \\
\hline
\end{tabular}


$\left[\mathrm{M}^{+}\right], 511(100)\left[\mathrm{M}^{+}-2 \mathrm{CO}\right] ; \operatorname{HRMS}(\mathrm{FAB}) ; m / z(\%)$ $[\mathrm{Err} / \mathrm{mmu}]=567.0081$ (10.7) $\left[+5.4\right.$ calc. for $\mathrm{C}_{24} \mathrm{H}_{21}{ }^{37}$. $\left.\mathrm{ClMnN}_{5} \mathrm{O}_{2}^{64} \mathrm{Zn}\right], \quad\left[+5.6\right.$ calc. for $\mathrm{C}_{24} \mathrm{H}_{21}^{35} \mathrm{ClMnN}_{5}$ $\mathrm{O}_{2}^{66} \mathrm{Zn}$ ]. Calc. for $\mathrm{C}_{24} \mathrm{H}_{21} \mathrm{ClMnN}_{5} \mathrm{O}_{2} \mathrm{Zn} \cdot \mathrm{CH}_{2} \mathrm{Cl}_{2}$ (652.16): C 46.04, H 3.55, N 10.73. Anal. Found: C 46.84, $\mathrm{H} 3.87, \mathrm{~N} 11.68 \%$. $\mathrm{C}$ and $\mathrm{N}$ values are somewhat higher than calculated due to partial loss of $\mathrm{CH}_{2} \mathrm{Cl}_{2}$.

\subsection{X-ray crystallography of 2 and 4}

The measurements were carried out on a Nonius Kappa CCD diffractometer using graphite-monochromated $\mathrm{Mo}-\mathrm{K}_{\alpha}$ radiation. All calculations were performed using the SHELXT PLUS software package. Structures were solved by direct methods with the SHELXS-97 and refined with the SHELXL-97 program [29]. Atomic coordinates and thermal parameters of the non-hydrogen atoms were refined in anisotropic models by full-matrix least-squares calculation based on $F^{2}$. In general the hydrogen atoms were placed at calculated positions and allowed to ride on the atoms they are attached to. Table 2 compiles the data for the structure determinations.

\section{Supplementary material}

Crystallographic data for the structural analysis have been deposited with the Cambridge Crystallographic Data Centre, CCDC no. 162375 and 163317 for compounds 2 and 4, respectively. Copies of this information may be obtained free of charge from The Director, CCDC, 12 Union Road, Cambridge CB2 1EZ, UK (Fax: +44-1223-336033; e-mail: deposit@)ccdc.cam. ac.uk or www: http://www.ccdc.cam.ac.uk).

\section{Acknowledgements}

Prof. Dr G. Huttner is sincerely thanked for his continuous generosity and his interest in our work. Financial support by the Deutsche Forschungsgemeinschaft (SFB 247, Heisenbergstipendium for F.M., Graduiertenkollegs-Stipendium for J.C.R.) and the Fonds der Chemischen Industrie is gratefully acknowledged.

\section{References}

[1] (a) J. Okuda, Comments Inorg. Chem. 16 (1994) 185; (b) C. Müller, D. Vos, P. Jutzi, J. Organomet. Chem. 600 (2000) 27;

(c) P. Jutzi, J. Dahlhaus, Coord. Chem. Rev. 137 (1994) 179.

[2] See for example: (a) I.L. Fedushkin, S. Dechert, H. Schumann, Organometallics 19 (2000) 4066;

(b) L.F. Groux, F. Bélanger-Gariépy, D. Zargarian, R. Vollmerhaus, Organometallics 19 (2000) 1507; (c) O. Segnitz, M. Winter, K. Merz, R.A. Fischer, Eur. J. Inorg. Chem. (2000) 2077;

(d) A.I. Philippopoulos, B. Donnadieu, R. Poilblanc, N. Hadjiliadis, J. Organomet. Chem. 582 (1999) 286;

(e) H. Schumann, E.C. Rosenthal, J. Demtschuk, G.A. Molander, Organometallics 17 (1998) 5324;

(f) P.T. Gomes, M.L.H. Green, A.M. Martins, J. Organomet. Chem. 551 (1998) 133;

(g) P. Foster, J.C.W. Chien, M.D. Rausch, J. Organomet. Chem. 545-546 (1998) 35;

(h) Z. Ziniuk, 1. Goldberg, M. Kol, J. Organomet. Chem. 545-546 (1997) 441;

(i) P.-J. Sinnema, L. van der Veen, A.L. Spek, N. Veldman, J.H. Teuben, Organometallics 16 (1997) 4245;

(j) A.K. Hughes, A.J. Kingsley, J. Chem. Soc. Dalton Trans. (1997) 4139;

(k) M. Enders, R. Rudolph, H. Pritzkow, Chem. Ber. 129 (1996) 459;

(l) W.A. Herrmann, M.J.A. Morawietz, T. Priermeier, K. Mashima, J. Organomet. Chem. 486 (1995) 291.

[3] (a) U. Siemeling, P. Jutzi, J. Organomet. Chem. 500 (1995) 175; (b) P. Jutzi, T. Redeker, Eur. J. Inorg. Chem. (1998) 663.

[4] See for example: (a) P.J. Shapiro, E. Bunel, W.P. Schaefer, J.E. Bercaw, Organometallics 9 (1990) 867;

(b) A.L. McKnight, R.M. Waymouth, Chem. Rev. 98 (1998) 2587 and references therein;

(c) R. Emrich, O. Heinemann, P.W. Jolly, C. Krüger, G.P.J. Verhovnik, Organometallics 16 (1997) 1511;

(d) M.S. Blais, J.C.W. Chien, M.D. Rausch, Organometallics 17 (1998) 3775;

(e) K.C. Hultzsch, T.P. Spaniol, J. Okuda, Angew. Chem., 111 (1999) 163; Angew. Chem. Int. Ed. Engl. 38 (1999) 227;

(f) P.T. Witte, A. Meetsma, B. Hessen, Organometallics 18 (1999) 2944.

[5] J.C. Röder, F. Meyer, H. Pritzkow, Organometallics 20 (2001) 811.

[6] See for example: (a) K.D. Karlin, Science 261 (1993) 701; (b) E.K. van den Beuken, B.L. Feringa, Tetrahedron 54 (1998) 12985;

(c) H. Steinhagen, G. Helmchen, Angew. Chem. 108 (1996) 2489; Angew. Chem. Int. Ed. Engl. 35 (1996) 2339.

[7] (a) F. Meyer, S. Beyreuther, K. Heinze, L. Zsolnai, Chem. Ber./Recueil 130 (1997) 605;

(b) F. Meyer, K. Heinze, B. Nuber, L. Zsolnai, J. Chem. Soc. Dalton Trans. (1998) 207.

[8] (a) F. Meyer, P. Rutsch, Chem. Commun. (1998) 1037; (b) F. Meyer, E. Kaifer, P. Kircher, K. Heinze, H. Pritzkow, Chem. Eur. J. 5 (1999) 1617;

(c) F. Meyer, I. Hyla-Kryspin, E. Kaifer, P. Kircher, Eur. J. Inorg. Chem. (2000) 771;

(d) J. Ackermann, F. Meyer, E. Kaifer, H. Pritzkow, Chem. Eur. J. (2001), in press.

[9] J.C. Röder, F. Meyer, R.F. Winter, E. Kaifer, in preparation.

[10] M. Enders, G. Kohl, H. Pritzkow, J. Organomet. Chem. 622 (2001) 66

[11] M.E. Huttenloch, J. Diebold, U. Rief, H.H. Brintzinger, Organometallics 11 (1992) 3600.

[12] Attachment of two $\mathrm{CpMn}(\mathrm{CO})_{3}$ units could be achieved starting from the dibromo derivative of 1 (see Ref. [9]).

[13] (a) W. Strohmeier, Angew. Chem. 76 (1964) 873 (Angew. Chem. Int. Ed. Engl. 3 (1964) 730);

(b) W. Strohmeier, F.-J. Müller, Chem. Ber. 102 (1969) 3608.

[14] D.M. Adams, A. Squire, J. Organomet. Chem. 63 (1973) 381.

[15] (a) [tmpaZnCl] $\mathrm{ClO}_{4}$ : C.S. Allen, C.-L. Chuang, M. Cornebise, J.W. Canary, Inorg. Chim. Acta 239 (1995) 29; (b) [tmpaZnCl] BPh 4 : H. Adams, N.A. Bailey, D. E. Fenton, Q.-Y. He, J. Chem. Soc. Dalton Trans. (1997) 1533. 
[16] Related tmpa-type systems: (a) J.W. Canary, C.S. Allen, J.M. Castagnetto, Y.-H. Chiu, P.J. Toscano, Y. Whang, Inorg. Chem. 37 (1998) 6255;

(b) N. Matsumoto, T. Akui, A. Ohyoshi, H. Okawa, Bull. Chem. Soc. Jpn. 61 (1988) 2250;

(c) J.W. Canary, C.S. Allen, J.M. Castagnetto, Y. Wang, J. Am. Chem. Soc. 117 (1995) 8484.

[17] A.W. Addison, T.N. Rao, J. Reedijk, J. van Rijn, G.C. Verschoor, J. Chem. Soc. Dalton Trans. (1984) 1349.

[18] Cambridge Structural Database search conducted in March 2001: F.H. Allen, J.E. Davis, J.J. Galloy, O. Johnson, O. Kennard, C.F. Macrae, E.M. Mitchell, G.F. Mitchell, J.M. Smith, D.G. Watson, J. Chem. Inf. Comput. Sci. 31 (1991) 187.

[19] Values versus the saturated calomel electrode (SCE). $i_{\mathrm{pa}} i i_{\mathrm{pc}}$ close to $1 ; i_{\mathrm{pc}} / v^{\frac{1}{2}} \approx$ const.; $\Delta E_{\mathrm{p}}=E_{\mathrm{p}}^{\mathrm{ox}}-E_{\mathrm{p}}^{\mathrm{red}}=80 \mathrm{mV}$ with $\Delta E_{\mathrm{p}}\left(\mathrm{C}_{\mathrm{p}_{2}} \mathrm{Fe} /\right.$ $\left.\mathrm{Cp}_{2} \mathrm{Fe}^{+}\right)=133 \mathrm{mV}$ under the same experimental conditions.

[20] K.G. Caulton, Coord. Chem. Rev. 38 (1981) 1.

[21] (a) L.I. Denisovich, N.V. Zakurin, S.P. Gubin, A.G. Ginzburg, J. Organomet. Chem. 101 (1975) C43;

(b) N.G. Connelly, M.D. Kitchen, J. Chem. Soc. Dalton Trans. (1977) 931 ;

(c) J.W. Hershberger, R.J. Klingler, J.K. Kochi, J. Am. Chem. Soc. 105 (1983) 61;

(d) N.G. Connelly, W.E. Geiger, Adv. Inorg. Chem. 21 (1984) 49;

(e) C.G. Atwood, W.E. Geiger, T.E. Bitterwolf, J. Electroanal. Chem. 397 (1995) 279.
[22] R. Groß, W. Kaim, Angew. Chem. 97 (1985) 869 (Angew. Chem. Int. Ed. Engl. 24 (1985) 856).

[23] W. Kaim, R. Gross, Comments Inorg. Chem. 7 (1988) 269.

[24] (a) J.P. Bullock, K.R. Mann, Inorg. Chem. 28 (1989) 4006 (b) D.T. Pierce, W.E. Geiger, Inorg. Chem. 33 (1994) 373.

[25] See for example: (a) D. Sellmann, J. Müller, P. Hofmann, Angew. Chem. 94 (1982) 708; Angew. Chem. Int. Ed. Engl. 21 (1982) 691;

(b) A. Winter, G. Huttner, L. Zsolnai, P. Kroneck, M. Gottlieb, Angew. Chem. 96 (1984) 986; Angew. Chem. Int. Ed. Engl. 23 (1984) 975;

(c) R. Groß, W. Kaim, Angew. Chem. 96 (1984) 610; Angew. Chem. Int. Ed. Engl. 23 (1984) 614;

(d) P. Lau, H. Braunwarth, G. Huttner, D. Günauer, K. Evertz, W. Imhof, C. Emmerich, L. Zsolnai, Organometallics 10 (1991) 3861 .

[26] (a) P.M. Zizelman, C. Amatore, J.K. Kochi, J. Am. Chem. Soc. 106 (1984) 3771;

(b) R. Gross, W. Kaim, Inorg. Chem. 25 (1996) 4865

[27] C.J. Qin, A. Gavrilova, B. Bosnich, Pure Appl. Chem. 73 (2001) 221.

[28] M. Krejcik, M. Daniek, F. Hartl, J. Electroanal. Chem. 317 (1991) 179.

[29] (a) G.M. Sheldrick, SHELXL-97, Program for Crystal Structure Refinement, Universität Göttingen, 1997;

(b) G.M. Sheldrick, sHELXs-97, Program for Crystal Structure Solution, Universität Göttingen, 1997. 